УДК 618.2-053.6

DOI 10.11603/2411-1597.2019.1.9979

\title{
ПРИЧИННО-НАСЛІДКОВІ ЗВ’ЯЗКИ ВИНИКНЕННЯ ПІДЛІТКОВОЇ ВАГІТНОСТІ
}

\author{
М. В. Наконечна, Н. В. Петренко, І. М. Дячок \\ ДВНЗ «Тернопільський державний медичний університет \\ імені І. Я. Горбачевського МОЗ Украӥни”
}

За результатами дослідження встановлено, що найчастішими причинами підліткової вагітності є ранній початок статевого життя, дефіцит знань щодо методів контрацепції та насильство, що зумовлює потребу розробки заходів щодо підвищення статевої культури молоді.

\section{CAUSE-AND-EFFECT RELATIONSHIP OF TEENAGE PREGNANCY}

\section{V. Nakonechna, N. V. Petrenko, I. M. Dyachok}

\section{Horbachevsky Ternopil State Medical University}

According to the results of the study the most common causes of teenage pregnancy are early onset of sexual activity, lack of knowledge about methods of contraception and violence, which prompt to the implementation of measures to increase the sexual culture of young adults.

Вступ. Серед сучасних проблем однією з суспільно важливих $є$ зниження віку початку статевого життя, що супроводжується зростанням кількості небажаної вагітності в цій категорії дівчат, а в подальшому призводить до штучного переривання вагітності, розширенням діапазону венеричних захворювань, появою серед школярок матерів-одиначок [2].

Соціально-економічна й інформаційна ситуація, що склалася в Україні, не лише формує самопочуття i впливає на систему цінностей дорослого населення, а й істотно позначається на молоді [3]. I найуразливішою виявляється така делікатна сфера людського життя, як статеві взаємини. Зміни, що відбуваються у цій сфері, зокрема ті, які стосуються дітей і неповнолітніх, не залишають ілюзій навіть прихильникам ліберальних поглядів на статеву мораль [1]. Як свідчать життєві спостереження і доводять спеціальні дослідження, нинішні діти доволі рано розпочинають свої статеві стосунки [7].

Так, за даними опитування, проведеного Інститутом соціальної і політичної психології Національної академії педагогічних наук України, середній вік початку статевого життя (показник, який в усьому світі вважається одним з найважливіших критеріїв ефективності освітніх програм із статевої просвіти молоді) становить 15,6 року [1, 3$]$.

(c) М. В. Наконечна, Н. В. Петренко, І. М. Дячок, 2019
Основна частина. Існує багато причин підліткової вагітності й не завжди причиною ранньої вагітності $\epsilon$ невігластво чи розбещеність [5]. Вагітність у цьому віці може настати внаслідок насильницьких дій партнера або примушення тощо [2, 7].

Численні дослідження, проведені в різних країнах світу, свідчать, що однією з основних причин ранньої вагітності $є$ низький рівень статевої освіти [6]. Уся відповідальність за статеве виховання лежить на плечах батьків, але далеко не всі приділяють цьому достатньо уваги [4]. У навчальних закладах роботу щодо сексуального виховання практично не проводять, а соціальні служби та центри планування сім'ї, як правило, надають допомогу вже після того, як ця проблема виникла [6].

у 2015-2017 рр. у Кропивницькому обласному центрі планування сім'ї та репродукції людини відбулося 25 пологів у дівчат віком до 18 років. Аналіз перебігу вагітностей у цих дівчат показав, що більшість з них (60\%) мала регулярні статеві стосунки, майже половина (40 \%) жила у громадянському шлюбі, причому четверта частина з них (25\%) до настання вагітності мала статеві стосунки з 2 і більше статевими партнерами. Притому майже третина (28 \%) не використовувала жодного методу контрацепції, а ще третина (28\%) - тільки природні методи [4]. 
Друга причина підліткової вагітності - зміна моральних норм суспільства, за якими сексуальне життя до шлюбу вважається нормою. За даними наукових джерел, 90 \% молодих людей до двадцяти років мають досвід сексуальних відносин [5]. Така сексуальна поведінка зумовлена вживанням алкоголю, поширенням еротичної та порнореклами, i, безумовно, властиве молодому і підлітковому віку бажання виділитися, відзначитися.

Третя причина підліткової вагітності - незнання правил контрацепції. Незважаючи на наявність і доступність методів контрацепції, підлітки, як правило, нехтують ними, що свідчить про необізнаність чи фінансову неспроможність [7].

Четверта причина підліткової вагітності - насильство. У даному випадку цей термін має більш широкий характер, ніж просто сексуальне насильство. Постійне побиття дівчаток-підлітків їхніми сексуальними партнерами, примушення до статевого акту - все це теж належить до насильства в підлітковому віці. Несприятлива сімейна атмосфера так само може впливати на цей факт і бути психологічним насильством для дівчинки [6].

Зважаючи на вищевказане, підліткова вагітність залишається значною медико-соціальною проблемою і потребує попередження ії виникнення. Саме тому нагальною проблемою сучасного суспільства $\epsilon$ статеве виховання молоді зокрема та підвищення статевої культури населення в цілому.

Статеве виховання - одна із складових моралі, тому, відповідно, за ії відсутності, неможливо вважати особистість всебічно розвиненою, високодуховною, гармонійною. Тривалий час існувала хибна думка, що питання статевих стосунків між чоловіком і жінкою вирішується приватно, індивідуально. Тому активне, відкрите обговорення цієї теми і пропагування знань, навіть із науковим підґрунтям, неетичне, непри-

\section{СПИСОК ЛІТЕРАТУРИ}

1. Андрієць О. А. Підліткова вагітність: актуальна проблема сьогодення / О. А. Андрієць, Л. В. Ринжук, О.І.Боднарюк // Акушерство. Гінекологія. Генетика. - 2016. - Т. 2, № 4. - С. 78-80.

2. Астахов В. М. Ювенильная беременность как психосоциальная проблема / В. М. Астахов // Акушерство. Гінекологія. Генетика. - 2016. - Т. 2, № 4. - С. 81-85.

3. Наймолодші мами у світі // Акушерство. Гінекологія. Генетика. - 2016. - Т. 2, № 4. - С. 96-98.

4. Наконечна М. В. Особливості підліткової вагітності в Кропивницькому та Кіровоградській області / М. В.На- стойне, до того ж - сприяє виникненню цікавості до статевих стосунків, психічних відхилень і вад.

На сучасному етапі розвитку суспільства одним із серйозних і першочергових завдань $€$ формування в підлітків правильних духовних установок, прищеплення толерантного ставлення до однолітків, зокрема і протилежної статі, виховання культури чистих і справжніх взаємин між статями. Здійснювати ці нелегкі завдання необхідно органічно вплітаючи в навчально-виховний процес. Шляхом правильного статевого виховання необхідно закласти основи майбутніх гармонійних подружніх відносин. У кожного підлітка повинен бути сформований моральний ідеал родини, розуміння її цінності й необхідності для людини. Родина є основою життєвого благополуччя, тому що вона сприяє збереженню здоров'я, полегшує перенесення життєвих труднощів.

До заходів профілактики підліткової вагітності повинні належати:

1) статеве виховання підлітків у навчальних закладах, демонстрації фільмів, проведення відповідних лекцій;

2) довірливі відносини з дитиною-підлітком, включно відверті розмови на «заборонені» теми;

3) представлення різноманітної та повної інформації про методи контрацепції.

Висновки. Дуже важливо пояснити підліткові, що бути дорослим - це не прийняття рішень, а вміння відповідати за власні вчинки, ранній початок статевого життя - це не просто ознака дорослості чи індивідуальності, а це дії, які мають наслідки, що можуть змінити майбутнє життя.

Нагальною потребою сьогодення $є$ підвищення статевої культури молоді, якої треба вчити, починаючи зі шкільної лави, в поєднанні з навчанням батьків, як виховувати дітей.

конечна, Н. В. Петренко // Медсестринство. - 2018. № 4. - C. 23-25.

5. Петрунько О. В. Актуальні проблеми сексуального виховання підлітків / О. В. Петрунько. - К. : ДЦССМ, 2014.

6. Потапова А. В. Поговорим откровенно : книга для среднего школьного возраста / А. В. Потапова. - К. : Веселка, 1988. - 232 с.

7. Halpern C. T. Testosterone predicts initiation of coitus in adolescent females / C. T. Halpern, J. R. Udry, C. Suchindran // Psychosom. Med. - 1997. - Vol. 59. - P. 161-171. 